\title{
Begonia yapenensis (sect. Symbegonia, Begoniaceae), a new species from Papua, Indonesia
}

\author{
Mark HUGHES ${ }^{1}$, Sadie BARBER ${ }^{1}$, Charlie D. HEATUBUN² ${ }^{2}$ Janet GAGUL ${ }^{3}$ \\ ${ }^{1}$ Royal Botanic Garden Edinburgh, 20a Inverleith Row, EH3 5LR, UK. \\ Emails: m.hughes@rbge.ac.uk (corresponding author); s.barber@rbge.ac.uk \\ ${ }^{2}$ Fakultas Kehutanan dan Pusat Penelitian Lingkungan Hidup, Universitas Papua, Jl. Gunung Salju, \\ Amban, Manokwari 98314, Papua Barat, Indonesia. \\ Email: charlie deheatboen@yahoo.com \\ ${ }^{3}$ Australian Tropical Herbarium, James Cook University, Cairns, QLD 4870, Australia. \\ Email: jgagul@yahoo.com
}

\begin{abstract}
A new species, Begonia yapenensis M.Hughes, in Begonia section Symbegonia (Begoniaceae) is described and diagnosed against Begonia sympapuana. The new species is endemic to Yapen Island, Papua, Indonesia, and is currently known from a single collection.
\end{abstract}

Keywords. Section Symbegonia, new species, endemic, New Guinea

Hughes M., Barber S., Heatubun C.D. \& Gagul J. 2015. Begonia yapenensis (sect. Symbegonia, Begoniaceae), a new species from Papua, Indonesia. European Journal of Taxonomy 119: 1-6. http://dx.doi.org/10.5852/ ejt.2015.119

\section{Introduction}

Begonia section Symbegonia (Warburg 1894: 149; Forrest \& Hollingsworth 2003: 208) is endemic to the island of New Guinea and comprises 13 species (Sands 2009). The section was recognised at the genus level prior to a molecular phylogenetic study (Forrest \& Hollingsworth 2003) which found it to be nested within Begonia section Petermannia (Klotzsch 1854: 124; de Candolle 1859: 128). The section is well defined morphologically by species having the tepals of the female flowers fused into a tubular corolla, the tepals of the male flowers often fused and usually with columnar androecia and unique endothecial cells in the anthers (Tebbitt \& MacIver 1999). However many of the species within the section are difficult to delimit. It is tempting to speculate that the large amount of highly dissected yet fairly continuous montane habitat on New Guinea has promoted rapid yet incomplete diversification in this group, leading to difficult species complexes. The tubular flowers are very different from those in other sections of the genus, and hence the pollination syndrome is likely to differ also. Increased population connectivity, possibly mediated by bird pollination, may also contribute to the persistence of widespread species complexes, which would otherwise fragment into different taxa in the absence of gene flow (Hughes \& Hollingsworth 2008). In addition to this biological complexity, the diversity in Begonia sect. Symbegonia is further difficult to interpret as the species have been described separately over the decades, most without reference to existing taxa and hence without comparative diagnoses. During preparation for a taxonomic revision of the section by two of the authors, it became clear that 
a recent collection from Yapen Island, Papua Province, Indonesia represents a new species which is described below.

\section{Materials and methods}

All available specimens of Begonia sect. Symbegonia in B, BM, BO, E, FI, K, L, P and SING were examined (272 sheets representing 171 collections), including the types for all names in the section in order to confirm the novelty of the collection from Yapen Island. The description was based on living material in cultivation at the Royal Botanic Garden Edinburgh and later pressed as the holotype. The terminology in the description follows Beentje (2010).

\section{Results}

Class Equisetopsida C. Agardh (Agardh et al. 1825)

Subclass Magnoliidae Novák ex Takht. (Takhtajan 1967)

Superorder Rosanae Takht. (Takhtajan 1967)

Order Cucurbitales Juss. ex Bercht. \& J.Presl (Berchtold \& Presl 1820)

Family Begoniaceae C. Agardh (Agardh 1824)

Genus Begonia L. (Linnaeus 1753)

Section Symbegonia

Begonia yapenensis M.Hughes sp. nov.

urn:Isid:ipni.org:names:77145852-1

Figs $1-2$

\section{Type}

INDONESIA. Cultivated collection 20 Aug. 2014, Barber SBAR86 (holo-: BO; iso-: E, MAN). Cultivated in the Royal Botanic Garden Edinburgh from vegetative material collected in the wild (Accession 20090830: Indonesia, Papua Province, Yapen Island, Ambaidiru, 1000 m, 18 Feb. 2009, Argent, Barber, Ensoll \& Galloway ABEG211).

\section{Description}

Sprawling much-branched caulescent herb to $20 \mathrm{~cm}$ high. Stem green, becoming woody at the base, internodes 3-5 cm long, pilose with $3 \mathrm{~mm}$ long white hairs. Stipules persistent, glabrous, narrowly triangular, caudate, 15-18 $\times$ 4-6 mm. Leaves: petiole $c a .5 \mathrm{~mm}$, pilose; lamina lanceolate, asymmetric, 8-10 $\times 2.5-4 \mathrm{~cm}$, midrib 7-9 cm, basifixed, base cordate, lobes not overlapping; upper surface rugose, green with purple-red veins, shortly hispid between veins, hairs $c a .1 \mathrm{~mm}$; underside paler than upper surface, shortly hispid on veins only; venation pinnate palmate; margin biserrate; apex acute-attenuate. Inflorescence terminal, total length 3-5 cm, cymose, compressed at first and becoming more elongate at maturity, unisexual or bisexual, protogynous, female flowers solitary or in pairs, basal, male flowers ca. 10-15; primary peduncle $3-13 \mathrm{~mm}$, shortly hispid; secondary peduncles shorter and glabrous; bracts 7-11 × 2-4 mm, linear-lanceolate, apex acute, white, glabrous. Male flower: pedicel 4-12 mm, white, shortly hispid; tepals 2, rhombic-ovate, fused just under half way, 10-13 $\times 8-10 \mathrm{~mm}$, white, shortly hispid at base, base bulbous, apex acute; androecium with 6-9 stamens, basal 5 subsessile, remainder on a thick $1 \mathrm{~mm}$ long column; filaments $0.5 \mathrm{~mm}$ long, white; anthers $1 \mathrm{~mm}$ long, burgundy, ellipsoid, pollen white. Female flower: pedicel 4-7 mm, pale green, shortly hispid, bracteoles present; ovary whitish green, total size $10 \times 19 \mathrm{~mm}$ including wings, wings 3 , subequal, triangular, up to $10 \mathrm{~mm}$ long, margin hispid; capsule ellipsoid, $8 \times 5 \mathrm{~mm}$, sparsely hispid, placentae 2 per locule; tepals 5 , corolla tubular, $c a$. $18 \times 8 \mathrm{~mm}$, petals fused for $\mathrm{ca} .3 / 4$ of the length, white, shortly hispid, hairs denser near the base, lobes ca. $5 \mathrm{~mm}$ long, apex acute; stigmas 3 , on a $1 \mathrm{~mm}$ style, length $7 \mathrm{~mm}$, forked for $2 / 3$ of the length, spirally twisted twice, pale yellow. Fruit on a stiff $c a .5 \mathrm{~mm}$ pedicel, total size including wings $11 \times 21 \mathrm{~mm}$. 


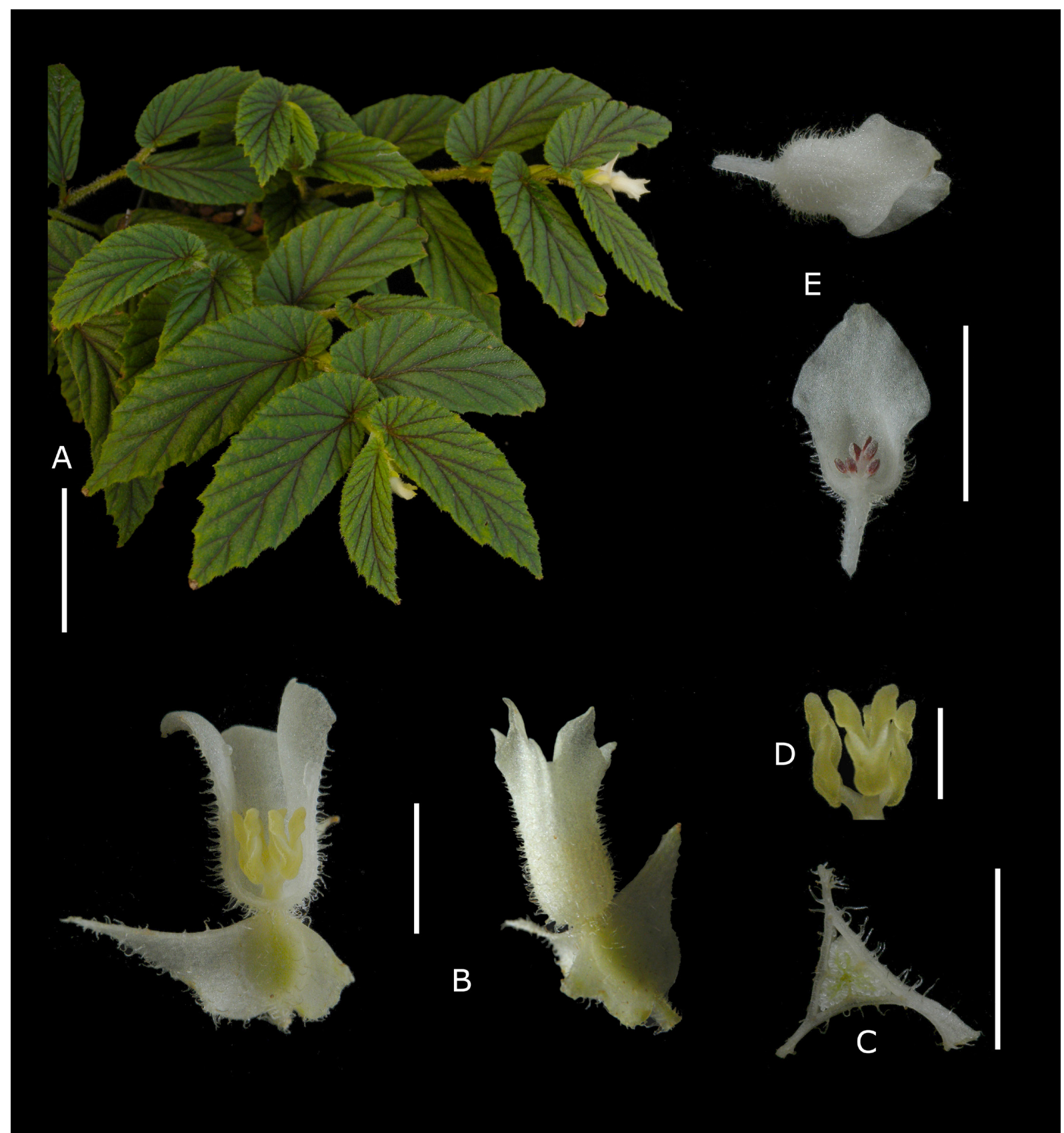

Fig. 1. Begonia yapenensis M.Hughes sp. nov., cultivated specimen at the Royal Botanic Garden Edinburgh, accession 20090830. A. Whole plant showing spreading habit (scale bar $=5 \mathrm{~cm}$ ). B. Female flower and ovary (left, corolla dissected; right, corolla entire) (scale bar $=1 \mathrm{~cm}$ ). C. Cross section of ovary showing three locules with bilamellate placentae $($ scale bar $=1 \mathrm{~cm})$. D. Stigmas (scale bar = $5 \mathrm{~mm}$ ). E. Male flower (bottom, corolla dissected; upper, corolla entire; scale bar $=10 \mathrm{~cm}$ ). 


\section{Distribution}

Indonesia. Only known from the type locality in central Yapen Island, Papua Province (Fig. 2).

\section{Habitat}

Collected in the forest around Ambaidiru village, away from disturbed areas on relatively unspoilt steep mountain sides with orange clay soil and large limestone boulders, near the top of the mountain at $c a$. 1000 m, in an Agathis grove showing signs of tapping for resin on the trunks. Understory vegetation in the area consists of Marattia Sw., Angiopteris Hoffm., Laportea Gaudich., Zingiberaceae Martinov, Aeschynanthus Jack, Begonia, Cyrtandra J.R.Forst. \& G.Forst., Pandanus L.f., Davallia Sm. and Selaginella P.Beauv.

\section{Notes}

Begonia yapenensis sp. nov. appears to be closest to Begonia sympapuana (Merr. \& L.M.Perry) L.L.Forrest \& Hollingsw. (Merrill \& Perry 1943: 59; Forrest \& Hollingsworth 2003: 208), which shares the rugose leaves with reddish veins and broadly similar inflorescences and flowers. Begonia yapenensis sp. nov. differs in being a smaller, lower growing plant with shorter internodes and a white undumentum (not reddish), the leaves having shorter petioles ( $c a .5 \mathrm{~mm}$, not $1-1.5 \mathrm{~cm}$ ), male flowers with tepals fused halfway (not shortly fused at the base) and fewer stamens (6-9, not $c a$. 15) which are arranged along a short column (not arising from a short torus), and fruits which have more attenuate wings. Plants of B. yapenensis sp. nov. in cultivation in deep shade show a blue iridescence of the upper leaf surface.

\section{Conservation status}

Data Deficient (DD; IUCN 2012). The conservation status of B. yapenensis sp. nov. is not known. The distribution and habitat information for this species is based on just one collection from Ambaidiru

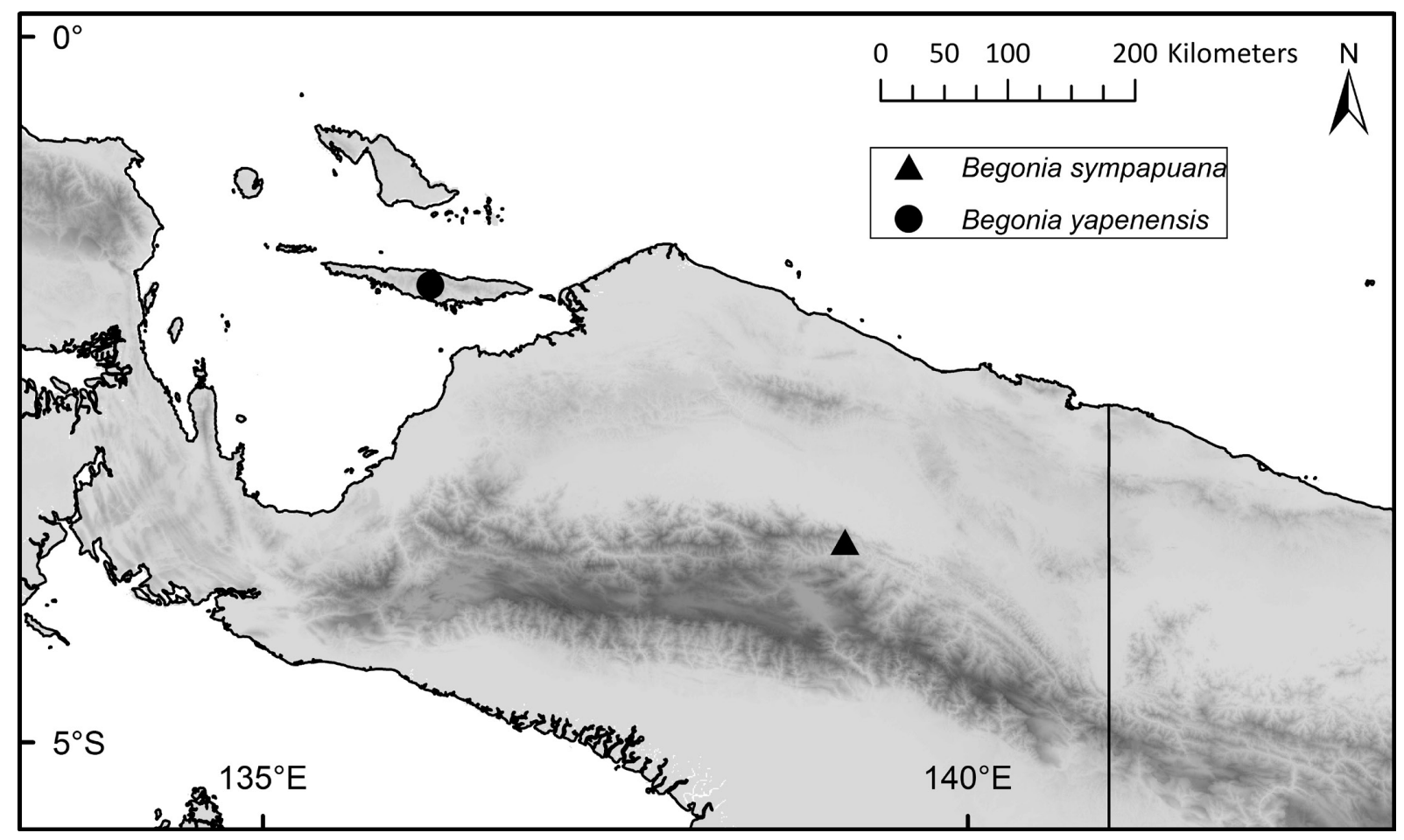

Fig. 2. Map of Tanah Papua, Indonesia, showing the distribution of Begonia yapenensis sp. nov. on Yapen Island, and of the allied Begonia sympapuana in the mountains at the head of the Idenburg River. 
village in the highlands of Yapen Island, Papua, Indonesia. Although the forest around Ambaidiru village is part of the Central Yapen Natural Reserve, the establishment of road access from south to north across the island within the protected area, as well as the expansion of Ambaidiru village, may affect the population of this Begonia. More population and distribution data are required to fully assess the conservation status of this species.

\section{Discussion}

Although known only from a single collection, the authors are confident in the novelty of $B$. yapenensis sp. nov. as it differs not only in habit, but also in androecium morphology from the most similar member of Begonia sect. Symbegonia, B. sympapuana. In cultivation, more careful measurement of B. yapenensis sp. nov. shows it to grow to $15(-20) \mathrm{cm}$ in height, with a horizontal spreading habit. The habit of B. sympapuana is difficult to discern as no living material is available, but the original description gives the height as $30-50 \mathrm{~cm}$, and it has much longer internodes consistent with an erect habit. The other species in Papua Province also differ considerably from B. yapenensis sp. nov.: B. arfakensis (Gibbs) L.L.Forest \& Hollingsw. (Gibbs 1917: 149; Forrest \& Hollingsworth 2003: 208) and B. symparvifolia (Gibbs) L.L.Forest \& Hollingsw. (Gibbs 1917: 150; Forrest \& Hollingsworth 2003: 208) have much smaller and more symmetric leaves; B. symgeraniifolia (Ridl.) L.L.Forest \& Hollingsw. (Ridley 1916: 61; Forrest \& Hollingsworth 2003: 208) has highly dissected leaves; B. pulchra (Ridl.) L.L.Forest \& Hollingsw. (Ridley 1916: 62; Forrest \& Hollingsworth 2003: 208) has glossy leaves which are glabrous above, and B. symhirta (Ridl.) L.L.Forest \& Hollingsw. (Ridley 1916: 61; Forrest \& Hollingsworth 2003: 208) has broadly ovate, subentire leaves.

\section{Acknowledgements}

The new taxon was collected on Yapen Island during the Papua expedition of the Royal Botanic Garden Edinburgh in 2009, which SB and CDH were involved. SB and CDH would like thank Kementerian Riset dan Teknologi Republik Indonesia, Lembaga Ilmu Pengetahuan Indonesia, Kebun Raya Cibodas, Balai Penelitian Kehutanan Manokwari, BKSDA Papua I Sub Seksi Pulau Yapen, authorities in Serui, people and chief of Ambaidiru village, George Argent, Andrew Ensoll, Louise Galloway and Herkilaus Rumaikewi. Financial support for the expedition was provided by the Royal Horticultural Society, the Merlin Trust, Royal Botanic Garden Edinburgh Members' Committee, and the James \& Eve Bennett Charitable Trust.

\section{References}

Agardh C.A. 1824. Aphorismi Botanici. Literis Berlingianis, Lund.

Agardh C.A., Holmberg L.P. \& Lundstrom P.M. 1825. Classes Plantarum. Literis Berlingianis, Lund.

Beentje H.J. 2010. The Kew plant glossary: an illustrated dictionary of plant terms. Royal Botanic Gardens, Kew, Richmond, Surrey.

Berchtold B.V. von \& Presl J.S. 1820. O prirozenosti rostlin, aneb rostlinár, obsahugjcj: gedánj on žiwobytj rostlinném pro sebe a z ohledu giných žiwotù, podlé stawu nyněgssjho znánj; $k$ rozssjřenj přirodnictwj; $w$ potaženj na užitečnost $w$ rolnictwj, hospodářstwj, řemeslech, uměnj i obchodu a w wztahowánj obzwlásstnjm na lekařstwj. Enders, Prague.

Candolle A.L.P.P. de 1859. Mémoire sur la famille des Bégoniacées. Annales des sciences naturelles. Botanique, sér 4 11: 93-149.

Forrest L.L. \& Hollingsworth P.M. 2003. A recircumscription of Begonia based on nuclear ribosomal sequences. Plant Systematics and Evolution 241 (3-4): 193-211. http://dx.doi.org/10.1007/s00606-002$\underline{0033-y}$ 
Gibbs L.S. 1917. A contribution to the phytogeography and flora of the Arfak mountains /by L.S. Gibbs. Taylor \& Francis, London. http://dx.doi.org/10.5962/bhl.title.894

Hughes M. \& Hollingsworth P.M. 2008. Population genetic divergence corresponds with species-level biodiversity patterns in the large genus Begonia. Molecular Ecology 17 (11): 2643-2651. http://dx.doi. org/10.1111/j.1365-294X.2008.03788.x

IUCN 2012. IUCN Red List Categories and Criteria: Version 3.1. Second Edition. IUCN, Gland, Switzerland and Cambridge, UK.

Klotzsch J.F. 1854. B. Monatsberichte der Königlich Preussischen Akademie der Wissenschaften zu Berlin 1854: 119-128.

Linnaeus C. 1753. Caroli Linnaei ... Species plantarum :exhibentes plantas rite cognitas, ad genera relatas, cum differentiis specificis, nominibus trivialibus, synonymis selectis, locis natalibus, secundum systema sexuale digestas... Laurentii Salvii, Stockholm.

Merrill E.D. \& Perry L.M. 1943. Plantae Papuanae Archboldianae XI. Journal of the Arnold Arboretum 24: 34-59.

Ridley H.N. 1916. Report on the botany of the Wollaston Expedition to Dutch New Guinea, 1912-1913. Transactions of the Linnean Society of London, 2nd Series: Botany 9 (1): 1-269.

Sands M.J.S. 2009. The Begonias of New Guinea - an overview. Blumea - Biodiversity, Evolution and Biogeography of Plants 54 (1): 272-277. http://dx.doi.org/10.3767/000651909X476274

TakhtajanA.L. 1967. Sistema ifilogeniia tsvetkovykh rastenii (Systema et Phylogenia Magnoliophytorum). Soviet Science Press, Moscow.

Tebbitt M.C. \& MacIver C.M. 1999. The systematic significance of the endothecium in Begoniaceae. Botanical Journal of the Linnean Society 131 (3): 203-221. http://dx.doi.org/10.1111/j.1095-8339.1999. $\underline{\text { tb00765.x }}$

Warburg O. 1894. Begoniaceae. In: A. Engler \& Prantle K. (eds) Die Natürlichen Pflanzenfamilien. Teil 3. Abt. 6A: 121-150. Englemann, Leipzig.

Manuscript received: 19 September 2014

Manuscript accepted: 27 February 2015

Published on: 10 April 2015

Topic editor: Thomas Janssen

Desk editor: Natacha Beau

Printed versions of all papers are also deposited in the libraries of the institutes that are members of the EJT consortium: Muséum national d'Histoire naturelle, Paris, France; Botanic Garden Meise, Belgium; Royal Museum for Central Africa, Tervuren, Belgium; Natural History Museum, London, United Kingdom; Royal Belgian Institute of Natural Sciences, Brussels, Belgium; Natural history Museum of Denmark, Copenhagen, Denmark. 